\title{
STRATEGI MASJID SABILILLAH MALANG DALAM PEMBERDAYAAN EKONOMI MASYARAKAT
}

\author{
Aki Edi Susanto \\ Universitas Islam Negeri Sunan Ampel Surabaya \\ akiedisusanto@gmail.com
}

\begin{abstract}
The Strategy of the Malang Sabilillah Mosque in Community Economic Empowerment". With the aim of this study is to understand and explore how the mosque's strategy in the economic empowerment of the people and to understand how the results of the mosque's strategy in the economic empowerment of the people. The research method used is to use a case study approach and descriptive qualitative research type. Data collection techniques using interviews, observation, documentation and study of literature, which is related to the strategy of the Sabilillah Mosque in Malang in empowering the economic community. The results showed that the community economic empowerment strategy used by the Sabilillah Mosque in Malang was to use two different empowerment programs, but the two programs were interrelated wih each other. Mosque cooperatives explore the potential of pilgrims who want to open a businesses, while LAZIS has a business development programs for the poor or needy to empower them from the economic side. Then the results of the empowerment strategy stated that the micro entrepreneurs who were given assistance from the mosque made their businesses grow and affect the economic welfare of the family.
\end{abstract}

Keywords: Strategy, Mosque, Empowerment.

\section{PENDAHULUAN}

Secara implisit, masjid memiliki peran yang penting bagi umat Islam dalam membentuk karakter untuk lebih agamis. Karena penting itulah, masjid harus difungsikan dengan sebaikbaiknya. Sehingga dapat dioptimalkan secara baik dengan pendirian dasar-dasar ketaqwaan (Pahlevi Hentika dan Rozikin, 2009). Apalagi masjid merupakan pranata keagamaan yang tidak dapat terpisahkan dari kehidupan spiritual, sosial, dan kultural umat Islam. Islam menempatkan masjid dalam posisi yang strategis.

Perspektif secara universal masjid berarti memahaminya sebagai sebuah instrumen sosial masyarakat Islam yang tidak dapat terpisahkan dari umat Islam itu sendiri. Keberadaan masjid umumnya merupakan salah satu perwujudan aspirasi dari umat Islam sebagai tempat ibadah yang menduduki fungsi sentral. Mengingat fungsinya yang strategis, sehingga perlu dibina dengan sebaik-baiknya, baik dari segi fisik bangunan maupun dari segi kegiatan pemakmurannya (Ridwanullah dan Herdiana, 2018). 
Susanto. Strategi masjid sabilillah malang dalam pemberdayaan ekonomi

Masjid sebagai tempat berkumpulnya umat sangat mungkin menjadi sebuah tempat yang efektif untuk melaksanakan kegiatan-kegiatan yang bersifat dakwah, pendidikan, sosial, ekonomi dan kesehatan. Dibeberapa masjid yang telah melakukan penataan manajemennya dengan baik, seperti masjid Sabilillah Malang, takmir masjid mampu memfungsikan masjid sebagai pusat kegiatan dakwah, pendidikan, sosial, kesehatan dan ekonomi. Karena inilah yang sangat dibutuhkan oleh masyarakat kita saat ini.

Masjid Sabilillah mempunyai kompetensi pengelolaan ekonomi, baik dari LAZIS maupun Koperasi Masjid Sabilillah dijalankan melalui pendampingan dan bina usaha. LAZIS terkonsentrasi khusus untuk kaum dhuafa dan juga fakir miskin yang ingin berwirausaha dan juga yang telah memiliki usaha dan ingin mengembangkan usahanya. Sehingga LAZIS Sabilillah menjembatani dan memberikan akses kepada masyarakat. Tidak hanya dalam bentuk uang, namun juga dalam bentuk sarana prasarana pendukung serta berbagai pembinaan serta motivasi dan pengetahuan pun diberikan untuk keluarga binaan yang terdiri dari kaum dhuafa. Adapun untuk program bina usaha, LAZIS Sabilillah mengeluarkan dana dari zakat infak dan juga shadaqah (ZIS) sebesar Rp. 92.328 .500 (Sabilillah, 2020).

Koperasi Masjid Sabilillah (KOPMAS), memberikan kemudahan bagi anggota untuk mengakses dana pinjaman, yaitu kelonggaran persyaratan dalam mengakses modal dipermudah dengan jaminan yang ringan, yakni seperti Kartu Keluarga (KK), surat nikah dan akta kelahiran anak. Kemudahan lainnya yang dapat diterima anggota ialah seperti tidak adanya denda yang dikenakan kepada anggota yang terlambat mengembalikan pinjaman. Hal ini menjadikan anggota Koperasi Sabilillah terus meningkat. Mayoritas anggota koperasi Masjid Sabilillah terdiri dari pedagang kaki lima, tukang parkir, penjahit, guru dan karyawan Masjid Sabilillah (Faizaturrodhiah et al., 2018).

\section{STUDI LITERATUR}

\section{Manajemen Strategi}

Manajemen adalah proses perencanaan, organisir, mengarahkan, dan mengendalikan kegiatan, untuk mencapai tujuan organisasi dengan menggunakan sumber daya dalam organisasi (Hubertus, 2016). Sedangkan strategi adalah penetapan tujuan jangka panjang dari suatu organisasi, pemilihan tindakan alternatif dan alokasi sumber daya yang dibutuhkan untuk mencapai tujuan organisasi. Kemudian strategi merupakan sesuatu yang dirancang dan disiasati secara cermat agar memberikan hasil atau keuntungan. Dalam organisasi perusahaan strategi selalu memberikan hasil yang baik, sehingga jika proses manajemen pada perusahaan tidak 
memberikan hasil yang lebih baik maka proses manajemen tersebut tidak dapat disebut manajemen strategis (Dewi dan Sandora, 2019).

Porter mengatakan manajemen strategi adalah penciptaan posisi unik dan berharga yang didapatkan dengan melakukan serangkaian aktivitas. Porter juga pernah menuliskan bahwa esensi dari manajemen strategi adalah memilih aktivitas yang tidak dilakukan oleh pesaing atau lawan (Manufaktur et al., 2014). Sedangkan Arthur A.J., mengatakan manajemen strategi terdiri dari aktivitas-aktivitas yang penuh daya saing serta pendekatan-pendekatan bisnis untuk mencapai kinerja yang memuaskan (sesuai target) (Wu et al., 2012).

\section{Pandangan Islam tentang Pemberdayaan}

Pemberdayaan adalah bentuk hubungan antara sesama manusia atau bagian dari muamalah. Karena dengan bermuamalah akan tercipta suatu masyarakat yang saling membantu satu dengan yang lain (Daulay, 2016). Masyarakat yang mempunyai kemampuan bisa membantu yang kurang mampu sehingga bisa mewujudkan dan menciptakan masyarakat yang mandiri dari sisi ekonomi. Allah SWT berfirman dalam QS. Al-Hajj ayat 41:

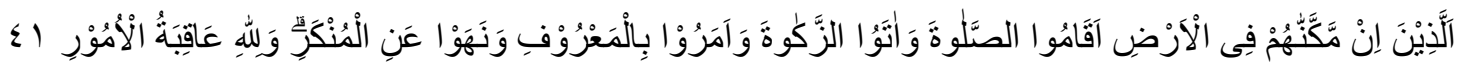
"(Yaitu) orang-orang yang jika Kami beri kedudukan di bumi, mereka melaksanakan salat, menunaikan zakat, dan menyurub berbuat yang makruf dan mencegah dari yang mungkar; dan kepada Allah-lah kembali segala urusan”.

Pemberdayaan masyarakat bagi umat Muslim merupakan konsep yang sangat urgen terutama dalam memberikan sudut pandang positif terhadap umat muslim yang kurang mampu. Islam menganggap kemiskinan sebagai keadaan yang tidak selaras dengan martabat manusia sebagai khalifatullah. Oleh karena itu, setiap manusia yang sehat secara fisik dan mental, diwajibkan untuk menopang dirinya dan keluarganya. Hal ini tidak akan terwujud kecuali bila disediakan fasilitas bagi mereka untuk melatih agar menjadi produktif melalui pemberdayaan kemampuan dan juga diberikan kesempatan untuk berwirausaha. Sehingga akan terjadi pemerataan pendapatan dan kesejahteraan sosial ekonomi.

\section{METODE PENELITIAN}

Penelitian yang digunakan yaitu jenis penelitian kualitatif. (Arikunto, 2002) mengatakan bahwa penelitian kualitatif merupakan jenis penelitian yang terjadi secara nyata dalam kondisi yang tidak direkayasa kejadian dan kondisinya. Penelitian ini menggunakan pendekatan 
Susanto. Strategi masjid sabilillah malang dalam pemberdayaan ekonomi

participatory action research, yang digunakan dalam pemberdayaan masyarakat ataupun kelompok dengan cara berinteraksi dan bersosialisasi secara langsung, sehingga akan menumbuhkan capacity building dan self confident masyarakat. Jenis penelitian yang digunakan merupakan penelitian deskriptif analitik (Sugiyono, 2008).

Unit analisis dalam penelitian ini adalah peran masjid. Sebagai tempat ibadah yang memiliki peran yang cukup luas, sehingga penelitian ini difokuskan pada program pemberdayaan ekonomi masyarakat, khususnya dalam bidang sosial ekonomi. Metode dalam pengambilan informan yang dipakai adalah Non Probability Sampling (Indriantoro dan Supomo, 2002). Dengan kriteria-kriteria informan yang ditentukan dalam penelitian ini adalah yang mempunyai pengetahuan mengenai masjid yang diteliti. Informan dalam penelitian ini adalah pengurus Masjid Sabilillah, yang terdiri dari Pimpinan Yayasan, dan pengurus yang diberikan tanggung jawab dalam program pemberdayaan di Masjid Sabilillah Malang. Serta juga masyarakat yang mendapatkan bantuan modal usaha dari LAZIS dan Koperasi Masjid Sabilillah.

Wawancara dilaksanakan dengan cara terbuka dan tidak terstruktur ketat. Observasi dilaksanakan secara langsung pada saat pengamatan lokasi dan penentuan informan di Masjid Sabilillah. Kemudian mengenai interpretasi data yang digunakan dalam penelitian ini didasarkan pada tahapan model alir, sebagaimana yang dikatakan oleh (Miles dan Huberman 1992). Adalah dengan pengumpulan data, reduksi data, dan penyajian serta verifikasi data berjalan secara simultan.

\section{HASIL PENELITIAN}

\section{Setrategi Pemberdayaan Ekonomi Umat}

Instrumen pemberdayaan ekonomi atau kegiatan usaha yang dimiliki oleh Masjid Sabilillah Malang yang dapat menunjang optimalisasi dalam pemberdayaan ekonomi jamaah, atau masyarakat sekitar. Sebagimana wawancara yang telah dilakukan bahwasannya Masjid Sabilillah Malang ini memiliki unit-unit yang menangani program-program masjid, seperti dalam hal pemberdayaan ekonomi umat, masjid ini telah membentuk dan mendirikan sebuah koperasi masjid. Sebagimana pernyataan dari Bapak Farkhan:

"Untuk pemberdayaan ekonomi masyarakat disini kami memiliki beberapa unit usaba yang menangani program itu seperti koperasi dan LAZIS, jadi semua di urus oleh koperasi, dan juga LAZIS. Jadi untuk program pemberdayaan ada di unit tersebut". 
Untuk itu dalam memaksimalkan peran dan fungsi masjid sebagai sentral bagi umat Islam dalam melakukan aktifitas, terutama aktivitas ekonomi maka Masjid Sabilillah Malang melakukan strategi yakni dengan cara mendirikan koperasi masjid. Sebagaimana pernyataan Bapak Farkhan:

"Kelembagaan tertinggi pada koperasi ini ialah Yayasan Masjid Sabilillah yang dibawahnya mempunyai divisi pemberdayaan ekonomi umat ada beberapa unit-unit usaha yaitu usaha parkiran, koperasi pujasera dan minimarket".

Dalam proses penyusunan strategi pemberdayaan ekonomi umat di Masjid Sabilillah Malang meliputi, Mengembangkan visi Masjid Sabilillah Malang yaitu menjadikan masjid sebagai pusat dakwah, pembinaan, pelayanan umat dan pusat pemberdayaan umat yang amanah dan professional, serta menjadikan masyarakat berdaya dan mandiri. Dengan melihat peluang yang sangat besar salah satunya dari banyaknya umat muslim sekitar yang harus diberdayakan walaupun banyak juga ancaman eksternal yang dihadapi Masjid Sabilillah Malang.

Hal tersebut juga melihat pula kekuatan yang dimiliki Masjid Sabilillah Malang yaitu dengan adanya sumber daya manusia yang berkualitas, meskipun dengan banyaknya SDM yang berkualitas namun ada beberapa kelemahan yang dihadapi yaitu bagi mereka yang sangat minim sekali rasa keumatan dalam diri mereka. Oleh karena itu Masjid Sabilillah Malang membuat divisi pemberdayaan yang didalamnya mempunyai beberapa program diantaranya adalah program pemberdayaan ekonomi umat. Sebagaimana penuturan dari Bapak Farkhan sebagai berikut:

"Kita memiliki divisi yang membuat survey khusus kepada masyarakat yang berada disekitar masjid, karena banyak keluarga yang memiliki kondisi ekonomi menengah kebawah guna untuk melihat permasalah yang dihadapi oleh jamaah dari survey tersebut".

Tujuan jangka panjang dari koperasi masjid adalah keberhasilan pelaku usaha mikro dari masyarakat/ jamaah. Hal ini sesuai dengan pernyataan dari bendahara koperasi Masjid Sabilillah Bapak Edy. "Proses jangka panjang dari koperasi masjid ini adalah melihat semangat masyarakat pelaku usaha mikro berhasil dalam menjalankan usahanya".

Implementasi strategi pemberdayaan ekonomi umat Masjid Sabilillah Malang yaitu menentukan tujuan tahunan minimal dalam satu bulan ada satu unit usaha yang sudah berkembang kemudian divisi ini membuat kebijakan, dan memotivasi jamaah sehingga strategi yang diformulasikan dapat terlaksana. Hal ini sesuai dengan pernyataan sekertaris koperasi Masjid 
Susanto. Strategi masjid sabilillah malang dalam pemberdayaan ekonomi

Sabilillah Malang Bapak Heru. "Jadi setiap bulan itu kami memiliki tujuan minimal satu unit usaha jamaah yang dapat kami kembangkan".

Selanjutnya evaluasi merupakan tahap akhir dalam sebuah strategi, evaluasi ini berfungsi untuk mengetahui apakah strategi berjalan dengan baik atau tidak. Divisi pemberdayaan ekonomi umat selalu mengadakan evaluasi pada setiap programnya, pada program koperasi. Sebagaimana pernyataan bendahara koperasi Masjid Sabilillah Malang Bapak Edy berikut ini.

"Untuk mengevaluasi yang namanya usaha yang pertama dilihat dari keuntungan dan kerugian, apabila usaha tersebut mendapatkan keuntungan berarti sudah bagus dan berdaya, nah kalau rugi kita lihat kesalahannya ada dimana kita lihat manajemennya kurang bagus, tidak diurus dengan baik, SDM kurang terampil, dan pendanaan uangnya bermasalah".

Dalam rangka memberdayakan pengusaha kecil Masjid Sabilillah Malang menyediakan lahan atau tempat bagi para pelaku usaha atau jamaah Masjid Sabilillah yang ingin berdagang atau usaha dipekarangan masjid. Koperasi juga memberikan bantuan modal bagi para jamaah yang ingin membuka usaha atau pedagang yang mau menambah modalnya guna untuk mengembangkan usaha. Berdasarkan pengakuan dari ketua koperasi Masjid Sabilillah Malang Bapak Sulaiman sebagai berikut:

"Adapun program pemberdayaan ekonomi yang dijalankan oleh koperasi masjid yaitu dengan pemberian modal usaba baik berupa uang ataupun peralatan perlengkapan yang dibutubkan oleb anggota, dengan sistem pinjaman tampa bunga (qardhul hasan), namun dengan memberikan infaq seikhlasnya. Sehingga tidak memberatkan anggota dalam proses pengembalian”.

Temuan dari hasil penelitian ini adalah masjid Sabilillah sudah menerapkan stretegi pemberdayaan ekonomi umat dengan baik namun kekurangannya adalah tidak dibarengi dengan pelatihan ataupun pendampingan. Sehingga masih ada nasabah yang kesusahan untuk proses pengembalian dana bahkan terjadi kredit macet. Jadi, pihak masjid harus bisa membuat program pelatihan dan pengawasan sehingga masalah kredit macet bisa dinetralisir.

\section{Hasil Strategi Masjid dalam Pemberdayaan Ekonomi Masyarakat}

Hasil dari program pemberdayaan ekonomi umat yang dilaksanakan oleh divisi pemberdayaan ekonomi umat Masjid Sabilillah Malang pada program koperasi dan juga LAZIS dalam upaya untuk meningkatkan perekonomian masyarakat ataupun jamaah dan juga 
pembiayaan bagi pelaku usaha mikro ini sudah terlihat dengan meningkatnya perekonomian mereka.

Selain meningkatnya perekonomian dalam memenuhi kebutuhan rumah tangga, mereka juga mendapatkan manfaat dan hasil lain yaitu berupa meningkatnya spiritual dan menjadi insan yang bertakwa didalam diri mereka. Karena selain berdagang mereka juga bisa mengikuti kajian-kajian yang diadakan oleh pihak Masjid Sabilillah Malang dan mereka juga bisa melaksanakan kewajiban terhadap Rabb-nya sehingga para nasabah tanpa harus terganggu dengan kegiatan jual beli. Selain itu mereka juga bisa menjalin hubungan tali silaturahmi antar jamaah. Sebagaimana pengakuan dari salah satu pedagang mie pangsit Pak Sur.

"Dengan adanya pembiayaan yang diberikan oleh koperasi masjid, saya merasa terbantu mas dari sisi kebutuhan ekonomi karena dagangan saya makin banyak. yang beli. Dan juga ada kegiatan kajian yang diberikan dimasjid sini. Sehingga ketika kita jualan dimasjid kalo ada kajian-kajian bisa ikut". "Untuk kebutuban ekonomi cukup untuk memenubi kebutuban keluarga, kalo dari sisi sosial kita sering ketemu dengan jamaah yang berdagang disekitar masjid dan juga para karyaman masjid sehingga bisa diskusi dan juga menjalin tali silaturabmi antar jamaah”.

Pernyataan tersebut diperkuat oleh Bapak Heru, selaku sekretaris koperasi masjid.

"Memang salah satu tujuan dari pendirian koperasi ini adalah untuk membantu masyarakat meminjam ke koperasi dari pada ke rentenir supaya tidak akan terlilit hutang. Dengan adanya bantuan modal dari koperasi Masjid Sabilillah diharapkan bisa membantu untuk meningkatkan pendapatan ekonomi masyarakat".

Dengan adanya Koperasi Masjid sebagai lembaga keuangan informal secara tidak langsung mempunyai peran yang cukup signifikan dalam membantu masyarakat yang mengalami keterbatasan dalam akses layanan keuangan. Sebagaimana yang dikatakan Chapra meyakinkan bahwa koperasi dilaksanakan sudah sesuai berdasarkan prinsip-prinsip Islam yang bertujuan pada pelayanan public.

Hal yang sama juga diungkapkan oleh program binaan dari LAZIS Masjid Sabilillah yaitu Ibu Liana dan Ibu Jumiati sebagai berikut:

'Dari LAZIS Sabilillah saya diberikan bantuan untuk menambah modal usaha, agar usaha saya bisa berkembang lebih baik. Dengan pemberian modal usaha dari LAZIS sehingga usaha saya 
Susanto. Strategi masjid sabilillah malang dalam pemberdayaan ekonomi

bisa laris dan semakin hari mendapatkan keuntungan bertambah.Sehingga kami bisa terbantu untuk. memperbaiki kehidupan ekonomi rumah tangga". "Dulu saya pernah meminjam dana untuk kebutuhan sehari-hari dan terlilit hutang dari rentenir, karena tidak bisa mengembalikan tepat waktu. Akbirnya saya meminta pertolongan ke LAZIS dan dikasib bantuan dan binaan. Kemudian saya diberikan bantuan modal usaba dan gerobak. Saya merasa bersyukur karena dengan bantuan itu akbirnya usaha saya mengalami perkembangan dan bisa melunasi semua butang-butang ke rentenir. Dan saya sekarang bisa menjadi anggota koperasi Masjid Sabililillab”.

Berdasarkan analisis penulis hasil dari pemberdayaan yang dilakukan oleh Masjid Sabilillah ini sudah bisa dikatakan berhasil, karena dari hasil wawancara menyatakan bahwa para pelaku usaha mikro yang mendapatkan bantuan pembiayaan dari koperasi bisa memenuhi kebutuhan ekonomi dan merasa terbantu dengan adanya koperasi Masjid Sabilillah. Sehingga bisa mengubah strata sosial yang dialami mereka dan menjadikan ekonomi keluarga meningkat. Namun pihak masjid harus lebih mengefektifkan program pembinaan kepada masyarakat yang diberikan modal usaha sehingga penyaluran program bisa menjadi lebih terarah dan sesuai dengan tujuan yang telah ditetapkan.

Tidak hanya sebatas itu, edukasi tentang ekonomi Islam dan pelatihan merupakan sebuah langkah dalam membentuk profesionalitas adalah langkah untuk meningkatkan keberhasilan dari program pemberdayaan, sehingga program tersebut dapat dirasakan dalam jangaka waktu yang cukup panjang. Karena saat ini masih minimnya program pendampingan yang dilakukan oleh LAZIS Sabilillah. Jadi, dengan meningkatkan spiritualitas adanya pengadaan kajian yang berupaya untuk menarik jamaah guna untuk memanfaatkan peluang dari banyaknya jamaah dari luar untuk datang ke masjid dengan memanfaatkan kekuatan SDM yang berkualitas, mayoritas anggota muslim, spirit pengurus dalam memakmurkan masjid, dan membantu masyarakat yang lagi kesusahan dari sisi ekonomi.

Membangun manusia seutuhnya, berarti membangun rohaniah manusia untuk menuju kesejahteraan hidup batiniyah dan meningkatkan kehidupan jasmaniah sebagai sarana untuk memperoleh kesejahteraan duniawi. Konsep Islam mengajarkan kehidupan yang seimbang antara kehidupan dunia dan kehidupan akhirat. Seperti yang terjadi dalam pelaksanaan program bina usaha, yang dilaksanakan secara seimbang pemantapan sikap, dan mental yang diorientasikan pada aspek spiritual. Untuk meningkatkan ekonomi mustabik perlu proses dan waktu yang tidak sebentar dan harus ada tindakan nyata agar tujuan tersebut tercapai, yaitu berkembangnya usaha dan meningkatnya ekonomi mustabik. Sehingga mustabik bisa mandiri dalam hal ekonomi. 


\section{SIMPULAN}

Berdasarkan hasil penelitian yang telah dipaparkan, maka dapat ditarik kesimpulan sebagai berikut: Berdasarkan strategi pemberdayaan ekonomi umat yang dijalankan oleh Masjid Sabilillah Malang menyatakan bahwa koperasi Masjid Sabilillah memberikan pembiayaan dengan persyaratan yang cukup mudah. Dan program yang dijalankan oleh koperasi Sabililillah yaitu mulai dari menyiapkan lokasi penjualan juga memberikan modal usaha, namun tidak dibarengi dengan pendampingan dan pengawasan dari pihak koperasi, sehingga anggota yang mendapatkan pembiayaan masih ada yang mengalami kesusahan dalam pengembalian dana pinjaman, bahkan ada sebagian yang terjadi kredit macet. Kemudian untuk program strategi yang dijalankan oleh LAZIS Sabilillah mereka mampu memberikan bantuan modal usaha dan juga ada program pendampingan walaupun kurang maksimal, sehingga banyak usaha binaan LAZIS yang dapat berkembang dan mampu menyejahterakan kebutuhan ekonomi keluarga.

Hasil dari strategi pemberdayaan ekonomi umat yang dijalankan oleh masjid Sabilillah menyatakan selain meningkatnya perekonomian dalam memenuhi kebutuhan rumah tangga, mereka juga mendapatkan manfaat dari hasil lain yaitu meningkatnya spiritual dan menjadikan diri mereka insan yang bertakwa. Karena selain berdagang mereka juga dapat mengikuti kajian yang dilaksanakan oleh masjid dan mereka bisa melaksanakan kewajiban kepada Rabb-nya tanpa harus terganggu dengan aktivitas jual beli. Selain itu mereka juga bisa menjalin tali silaturahmi antar jamaah.

\section{REFERENSI}

Arikunto, Suharsimi. 2002. Metodologi Penelitian. Jakarta: PT. Rineka Cipta.

Daulay, Raihanah. 2016. Pengembangan Usaha Mikro Untuk Pemberdayaan Ekonomi Umat Di Kota Medan. Jurnal Miqot Vol. XL, No. 1. Januari-Juni 2016.

Dewi, R., dan Sandora, M. 2019. Analisis Manajemen Strategi UIN Suska Riau Dalam Mempersiapkan Sarjana yang Siap Bersaing Menghadapi MEA. Jurnal El-Riyasah, 10(1), 74.

Faizaturrodhiah, $\mathrm{N}$ et al. 2018. Peran Institusi Masjid Sebagai Pusat Pemberdayaan Sosial Ekonomi Masyarakat Studi di Masjid Sabilillah Malang.

Ife, Jim. 1995. Community Development: Creating Community Alternatives, Vision, Analysis And Practice, Australia: Longman.

Indriantoro, Nur dan Bambang Supomo. 2002. Metode Penelitian Bisnis Untuk Akuntansi dan Manajemen. Yogyakarta: BPFE, Edisi Pertama.

Manufaktur, P., et al. 2014. Jurnal Manajemen Strategi Bisnis dan Kewirausahaan Volume 8 Nomor 1 Tabun 2014. 8 . 
Susanto. Strategi masjid sabilillah malang dalam pemberdayaan ekonomi

Miles, Mattheu B. dan Huberman, A. Michael. 1992. Analisis Data Kualitatif. Jakarta: Universitas Indonesia.

Mukrodi. 2014. Analisis Manajemen Masjid Dalam Optimalisasi Peran Dan Fungsi Masjid. Kreatif, Jurnal Ilmiah Prodi Manajemen Universitas Pamulang, 2(1), 82-96.

Pahlevi Hentika, N., dan Rozikin, M. 2009. Studi pada Masjid Al Falah Surabaya. Jap), 2(2), 305311.

Ridwanullah, A. I., dan Herdiana, D. 2018. Optimalisasi Pemberdayaan Masyarakat Berbasis Masjid. Ilmu Dakwah. Academic Journal for Homiletic Studies, 12(1), 82-98.

Rusmalita, S. 2016. Potret Manajemen Masjid Di Pedesaan. Al-Hikmah, 10(1). https://doi.org/10.24260/al-hikmah.v10i1.548.

Subianto, Achmad. 2004. Ringkasan dan Bagaimana Membayar Zakat. Jakarta: Yayasan Bermula dari Kanan.

Sugiyono. 2008. Metode Penelitian Kuantitatif, Kualitatif dan R \& D. Bandung: Alfabeta.

Sumodiningrat, Gunawan. 1999. Pemberdayaan Masyarakat dan Jaringan Pengaman Sosial, Jakarta; Gramedia Pustaka Utama.

Wu, M., Yan, C., Zhang, D., Wu, W., \& Li, H. (2012). P-268. Epidemiology, 23(36), 1. 